\title{
Why Were There So Many Jews in SDS? Or, The Ordeal of Civility
}

\author{
Mark Rudd
}

I've been thinking about this subject for a long time, almost forty years. I first spoke publicly about the question in 1988 at the twentieth anniversary celebration of the Columbia strike. In a rambling 45 minute monologue I touched on a lot of subjects, but the only one people seemed to respond to was my recognition of our Jewish backgrounds as relevant to our opposition to the war and racism. That was during a mini-revival of Judaism and Jewish culture which took place among the not so new New Leftists in the 80's. With the death of the socialist dream we were all searching for direction at the time. Unfortunately, I haven't pursued the subject until now, but I do believe that the revolt of Jewish youth in the New Left of the sixties and seventies deserves to be studied and honored as an important chapter in the history of American Jews. [1]

Before beginning to write, I checked out the subject on the internet. Googling the words "Jews and SDS," the number two site that popped up was a page from "Jew Watch," which monitors the ZOG, that is the Zionist Occupation Government of the United States. The piece was called, "How the Jews Controlled the New Left of the 1960's." Reading down, I found some decent scholarly references concerning the numerical preponderance of Jewish leaders and rank-and-file members of the New Left and SDS, at least until the late 1960's. But at one point, with no warning, the anonymous author suddenly flips into analysis mode with this paragraph:

\begin{abstract}
Radical Jewish students tended to come from liberal if not radical homes. While their parents might express some opposition, often on tactical grounds, they were generally quite supportive. Indeed, many Jewish parents spoke with pride of their "revolutionary" children. During the 1968 Columbia upheavals, Mark Rudd's mother commented: "My revolutionary helped me plant these tulips last November, my rebel." Rudd, in turn, according to the same New York Times story, speaks of his parents with respect and affection, and they maintain that they are " 100 percent behind him," even though they don't agree with all his views. On Mother's Day (during the riotous period at Columbia) his parents went to the Columbia campus and bought a veal parmigiana dinner, which the family ate in their parked car on Amsterdam Avenue. [New York Times, May 19, 1968, p. 1.]
\end{abstract}

I'm not sure whether the author is jealous of the close, accepting Jewish family, or more likely, merely Jewish humor-impaired, not recognizing my mother's obvious sarcasm.

Originally I was astounded that a quote from my dear mother, Bertha F. Rudd-now age 93 and still healthy and sharp-as-a-tack, living in the Lester Senior Housing Independent Living Apartments of the Jewish Community Housing Agency at the Metrowest Jewish Community Center, in Whippany, N.J. — would appear on a rabidly antisemitic website. But then I remembered that Bertha had served as the model for Woody Allen's mother in the 1989 movie "New York Stories, Oedipus Wrecks" in which his mother appears in the sky over Manhattan to tell the whole city about his shortcomings.

Anonymous anti-semites aside, the numbers on Jews in SDS are clear. The author Paul Berman, himself a Jewish veteran of Columbia SDS, in his excellent book, "A Tale of Two Utopias," gives the following data from reliable sources: two-thirds of the white Freedom Riders who traveled to Mississippi were Jewish; a majority of the steering committee of the 1964 Berkeley Free Speech Movement were Jewish; the SDS chapters at Columbia and the University of Michigan were more than half Jewish; at Kent State in Ohio, where only 5 percent of the student body 
was Jewish, Jews constituted 19 percent of the chapter. I might add a strange statistic which I became aware of in the course of two trips to Kent State to commemorate the events of May, 1970: three of the four students shot by the National Guard at Kent State were Jewish. This, of course, defies all odds.

There are at least two good ways to pursue the question of why there were so many Jews in SDS. The first would be a sociological research study in which a large representative sample of the Jewish veterans of SDS and the New Left are asked about the relationship between their being Jewish and their activism. The responses would be classified and quantified. I hope somebody does this, if it hasn't already been done. The second approach, ethnographic case study, is the one I propose to pursue. And, surprise, the case study will be myself, as representative of the cohort. So here goes:

My father, Jacob S. Rudd, born Jacov Shmuel Rudnitsky in Stanislower, Poland, immigrated to the United States in 1917, when he was nine years old. My mother, Bertha Rudd, was born Bertha Bass, in Elizabeth, New Jersey, in 1912, the year after her parents immigrated from Lithuania, the only child of the family born in this country. My family was part of the great wave of Eastern European Jewish immigration which lasted from 1880 to about 1920.

Both my parents were raised in Elizabeth, N.J., speaking Yiddish at home and English outside the house. My mother graduated high school, and my father went to Rutgers, the State University, on a scholarship. Though he graduated as an electrical engineer in 1932, he couldn't find work in the depths of the depression so he went into the Army as a reserve officer and ran CCC camps. For three years my parents were stationed in Blanding, Utah, a world away from Elizabeth, N.J. Stories I heard and photos I saw as a child generated in me a fascination with the Southwest, which might have been an important factor in my transplanting myself here years later.

My father served as an officer during World War II, both at home and in the Philippines. After the war he continued in the reserves, eventually rising to the rank of Lieutenant Colonel, which he was very proud of. Someone had told him that a Rudnitsky could never rise above the rank of Captain, so in 1954 he shortened his name-and mine-which seemed to do the trick.

I was raised in the town of Maplewood, N.J., a near-by suburb of Newark. My grandmother on my mother's side ran a "candy store," what we would probably now call a convenience store, in a mixed-Irish-Italian-Jewish-black neighborhood of Newark, a very old industrial city. From 1945 to 1967, an entire flourishing community of about 100,000 Jews packed up and left Newark for the suburbs to the west. The story of the Newark Jews, including the flight to the suburbs, has been brilliantly chronicled by Philip Roth, starting with "Goodbye Columbus" in 1959, up to today, with "The Plot Against America," published in 2004. Roth is about 15 years older than I am; the world he describes is precisely one-half generation earlier than the one I grew up in. It's no surprise that he has always been one of my favorite authors, though my mother can't stand him since Maxine Grofsky's mother used to sit next to her in shul. Mrs. Grofsky had nothing good to say about Philip. Maxine was the girl that Philip was going with right before he wrote "Goodbye Columbus." The story skewered rich suburban Jews and also there was something about a diaphragm, you might recall. The incident was very difficult for the Grofsky's and for my mother. Bertha never liked Roth after that.

I invoke Roth to let you in on the insularity of the world I grew up in. My family carried the Jewish ghettos of Newark and Elizabeth with them to the suburbs. We may have lived in integrated neighborhoods, that is integrated with goyim (there were only a few blacks in the town) and we may have gone to integrated schools, (of course there were no blacks in my elementary school) but we were far from assimilated, if that means replacing a Jewish identity with an American one. At about the age of nine or ten I remember eating lunch at the house of a non-Jewish friend and reporting back that the hamburgers had onion and parsley in them. "Oh, that's goyish hamburger," my mother said. I lived a Philip Roth existence in which the distinction between Jews and gentiles was present in all things: having dogs and cats was goyish, for example, as was a church-sponsored hay-ride which I was invited to by the cute red-haired girl who sat in front of me in my seventh grade home-room. My parents didn't allow me to go, and, since repression breeds resistance, that was probably a signal event in my career of fascination with shiksas and things goyish, a career which paralleled that of young Alexander Portnoy in "Portnoy's Complaint."

The center of my parents' social world was Congregation Beth El in South Orange, N.J. After my father achieved a certain level of success in the real estate business he was asked to join the Congregation Board. That was well after I had left for college. In his retirement years he took charge of the upkeep of the building and grounds. My mother was active in the local chapter of the National Council of Jewish Women and ran the temple's gift shop, selling candy and bagels to the Hebrew school kids. Neither being particularly religious, we were minimally observant. I attended Hebrew School quite dutifully, though, and services, too, at least until the year after my bar mitzvah. I even became 
President of the Junior Congregation, conducting services on Saturday mornings for the kids. I was a perfect little Jewish boy in my suit and tie, tallis, and, occasionally, tefillim.

However, it was on or about my bar mitzvah that it occurred to me, like happens to so many other Jewish kids, that God probably doesn't exist, that He's a social construct, just like all other gods. In retrospect I realize that I never had the faith very deeply. God wasn't a very active member of Congregation Beth El. I think He had missed the move out of Newark. There, my grandmother was still maintaining the old orthodox faith, observing the Sabbath and keeping kosher. Years after her death I realized for the first time that she had never once eaten a meal at our house in Maplewood, since we were not kosher. That was the price my mother paid for having rejected her mother's old religion as just so much superstition.

As a teenager, Congregation Beth El seemed to me just another aspect of the suburban scene: materialist and hypocritical. This was the time of the civil rights movement, but the lily-white suburbs existed in order to escape the "schvartzes." Jews in my parents' and grandparents' milieu used this derogatory term in exactly the same way southerners used "nigger." "The schvartze is coming to clean the house." "The schvartzes robbed my hardware store in Newark." "I had to sell the apartments on Clinton Avenue because schvartzes moved next door." There was no phony liberalism about the race war in Newark and Maplewood, at least not that I could see. Oh, yes, there was the local branch of the Ethical Culture Society, which consisted of Jews so removed from their roots that they couldn't even remember they had once been Jews. They were the town liberals, and it was only later that I got to know them.

In the early sixties I was mostly influenced by the beats in poetry and by the folk-song movement. Pete Seeger wasn't very Jewish, his ancestors having come over on the Mayflower, I think, though many of the communists around him were. Israeli folk-songs of the time had a whiff of socialism about them, but labor anthems rang in my head. I learned the songs of the Spanish Civil War, Bertold Brecht, the Wobblies, the union movement, blues via Leadbelly and Sonny Terry and Brownie Magee. The Harlan County miners' "Which Side Are You On?" was not the music of the Jewish suburbs. I wanted out.

I got to Columbia University as a freshman, age 18, in September, 1965, a few months after the United States attacked Vietnam with main force troops. There I found a small but vibrant anti-war movement. In my first semester I was recruited by David Gilbert, a senior who had written a pamphlet on imperialism for national SDS, Students for a Democratic Society. David was one of the founders of the Columbia SDS chapter, along with John Fuerst, the chapter Chairman. Both were Jewish, of course, as were my mentors and friends, Michael Josefowicz, Harvey Blume, Michael Neumann, and John Jacobs. Ted Kaptchuk and Ted Gold were Chairman and Vice-Chairman of Columbia SDS the year before I was elected Chairman, along with my Vice-Chairman, Nick Freudenberg. All of us were Jewish. It's hard to remember the names of non-Jewish Columbia SDS'ers; it was as much a Jewish fraternity as Sammie. There were probably a greater proportion of gentile women than guys in SDS, and of course I got to know them.

Out of all the uncountable hours of discussion in SDS meetings, at the West End Bar over beer, and in our dorm rooms and apartments over joints, I don't remember one single conversation in which we discussed the fact that so many of us were Jewish. This glaring lack alone might serve as a clue to what we were up to: by being radicals we thought we could escape our Jewishness. Left-wing radicalism was internationalist, not narrow nationalist; it favored the oppressed and the workers, not the privileged and elites, which our families were striving toward. Moreover, we were New Leftists, having rejected the sectarianism and cant of the Old Left, which, of course was dominated by Jews.

My friends in SDS taught me, quite correctly, that the world was in revolt against U.S. domination. That was why the Vietnamese were fighting so hard. I learned to admire the Vietnamese and the Cubans and the Chinese and the Russian peasants who had stood up to make a new society. Identifying with the oppressed seemed to me at Columbia and since a natural Jewish value, though one we never spoke of as being Jewish. We were socialists and internationalists first. I myself joined the cult of Che Guevara, putting posters of him on my apartment wall and aching to be a revolutionary hero like him. He wasn't very Jewish, incidentally.

But World War II and the holocaust were our fixed reference points. This was only twenty years after the end of the war. We often talked about the moral imperative to not be Good Germans. Many of my older comrades had mobilized for the civil rights movement; we were all anti-racists. We saw American racism as akin to German racism toward the Jews. As we learned more about the war, we discovered that killing Vietnamese en masse was of no moral consequence to American war planners. So we started describing the war as racist genocide, reflecting the genocide of the holocaust. American imperialist goals around the world were to us little different from the Nazi goal of global 
conquest. If you really didn’t like somebody—and we loathed President Lyndon B. Johnson—you might call him a fascist.

Columbia SDS adopted an intelligent strategy of protesting the war by opposing the university's involvement with it. Over a three year period we exposed the University's claims of being “value-neutral” by pointing to Columbia's Naval ROTC program, its allowing Marine and CIA and Dow Chemical recruiting, and, finally, the defense-oriented research work of the Institute for Defense Analysis consortium, of which Columbia was a leading-and secretmember. Support for the anti-war position among students and faculty gradually grew as the war escalated and as the SDS chapter engaged in continual educational activities and confrontations. The conflict with the university over the war and racism came to a head in the massive rebellion and strike of April-May, 1968.

What outraged me and my comrades so much about Columbia, along with its hypocrisy, was the air of genteel civility. Or should I say gentile?

Despite the presence of so many Jews in the faculty and among the students-geographical distribution in the admissions process had not been effective at filtering us out, our SAT's and class-rank being so high-the place was dripping with goyishness. When I got there freshmen still wore blue blazers and ties and drank sherry at afternoon socials with the deans. I had a classmate named Billy Schwartz who played rock guitar. He was the nephew of the most famous of all Columbia English professors, Lionel Trilling. Turns out Professor Trilling had once been Leon Schwartz, but had changed his name in order to advance up the academic ladder, not unlike my father in the U.S. Army. At the top of the Columbia heap sat President Grayson Kirk and Vice-President David Truman, two consummate liberal WASP's who privately claimed to oppose the war but maintained the institution's support of it.

In an infamous rabble-rousing speech I made in the course of one the confrontations on campus, I referred to President Grayson Kirk as "that shithead." Certainly I reveled in my role of head barbarian within the gates. But also I wanted to de-throne the President of Columbia University in the minds of my fellow students. It worked.

More than twenty years ago I read a book called, "The Ordeal of Civility: Freud, Marx, Levi-Strauss and the Jewish Struggle With Modernity." The author, an Irish-American sociologist named John Murray Cuddihy, advances a fascinating theory on the origins of Marxism and Freudianism. Jews were newly emancipated, that is, given legal and political rights, in Western Europe in the mid to late nineteenth century. But even bourgeois Jews were still excluded from civil society by customs and especially by manners. As Jewish (or formerly Jewish) outsiders ostensibly allowed in, but not really, Marx and Freud brought critical eyes to European bourgeois society. Marx said, in effect, "You think you've got yourself a fine little democracy here, well let me tell you about the class exploitation and misery that's underlying it." Similarly, Freud exposed the seamy, sexuality-driven motives, the up-raised penises controlling the unconscious minds of civilized, well-mannered bourgeois society.

We Jews at Columbia_-and I would guess at colleges throughout the country-brought the same outsider view to the campuses we had been allowed into. We were peasant children right out of the shtetls of New Jersey and Queens screaming, "You want to know the truth about Columbia University, they're a bunch of liberal imperialists! They claim to be value-neutral but when we asked them to stop their research for the Vietnam War and their racist expansion into the Harlem community, they not only ignored us, but they called out the cops to beat us up and arrest us. Up against the wall, motherfucker, this is a stickup!" Morally and emotionally we could not fit into the civilized world of the racist, defense-oriented modern university. Such was our ordeal of civility.

Only a few of us came to Columbia from red-diaper backgrounds, children of communists. We were good Jewish kids, the cream of the crop, who had accepted the myths of America-democracy, opportunity for all, good intentions toward the world — and of the university - free and open inquiry toward the truth. We were betrayed by our country and the university when we learned, in a relative instant, that the reality wasn't even close to these myths. We third generation American Jews suddenly woke up and realized this country may have been a blessing for us, but not for so many others who couldn't pass for white. I should add that non-Jewish friends and comrades in the New Left experienced very similar feelings of betrayal and outrage, though coming from different backgrounds.

In the midst of the Columbia strike, a downtown theater company came to the campus to perform for us a revival of an old Yiddish play, "The Gymnasium." About 1,000 students packed the auditorium of the student center to see it. It's a classic story of the struggle of a Jewish family in Poland to get their son into the city's high school, the gymnasium. First the boy is rejected because he's Jewish, then the family is told he can attend the gymnasium if they sponsor a gentile also. So they go out and find a gentile boy, get him through the entrance tests, pay for him, and the two boys are admitted. It's a saga. In the last scene, the boys come home early from school. The mother is in the kitchen. She asks what's wrong. The son replies, "Mother, it's wonderful, the gymnasium is closed. We're on strike 
against the quota system!" The mother collapses, and as she does so, all of us in the audience jump up, screaming at the top of our lungs, "Strike! Strike! Strike!," raising our hands in the V sign, tears streaming down all our faces.

Perhaps our anger was derived in some unconscious way from the famed prophetic tradition in Judaism, but I had never experienced any of it. Our rabbi at Congregation Beth El, Dr. Theodore Friedman, never to my knowledge preached about the legal discrimination against Negroes in the South, even as the civil rights movement raged on for more than a decade. Nor did I ever hear mention in shul of any relationship between those of us in the all-white suburbs to our black neighbors in adjacent Newark, N.J., other than thankfulness that we had gotten the hell out of there.

This is not to say that there weren't decent rabbis and Jewish leaders who were active in civil rights. Years later I became aware of Rabbi Joachim Prinz of Temple B'nai Abraham in Newark, and Rabbi Abraham Joshua Heschel of the Jewish Theological Seminary in New York, both side-kicks of Dr. Martin Luther King. They are said to have been very influential, though I didn't know about them at the time.

From my own experience I'm forced to disagree with the theory that there's something special and inherent in our religion which leads us to social activism, altruism, and the left. My former rabbi, Lynn Gottlieb, was fond of telling us that the Torah enjoins us to "honor the stranger because we were strangers in Egypt" forty-six or one hundred and seventeen times. Whatever the number, it was probably one of those laws that needed to be reiterated continually because nobody was observing it.

Dr. Israel Shahak, recently deceased, was a Hebrew University Chemistry Professor, President of the Israeli League for Human and Civil Rights, and a holocaust survivor. For many years he occupied a place in Israeli politics roughly the same as Noam Chomsky in this country. In a book entitled, "Jewish History, Jewish Religion: The Weight of Three Thousand Years," he argues that as a reaction to being the victims of racism throughout the centuries, we developed a religion which itself enshrined racism toward the other. This is especially true of the rabbinical commentaries developed in Eastern Europe over the almost one thousand years in which we occupied a middle position between the landlords, whom we served, and the peasants who despised us and whom we in turn despised. How could it have been otherwise? In my family, if you wanted to say somebody was stupid you said they had a "goyishe kup," a goyish head.

My intention here is not to single out Judaism as being worse than other religions. It is just to say that we are no better. As a kid in Maplewood I never heard of tikkun olam, the now well-known commandment to repair the world. For all I know, Michael Lerner — whose parents, incidentally sat near my parents in shul at Beth El—made the whole thing up.

I am so obviously Jewish that no matter how much carne adovada or fry bread I eat, I'm instantly recognizable as a Jew. I proudly acknowledge the drive for education in Jewish culture which made me want to read about the world and to understand it and to become a teacher. I also recognize that in my social activism I am one of thousands working in the grand tradition of Jewish leftists, the Trotskys and the Emma Goldmans and the Goodmans and Schwerners of the twentieth century. I honor this lineage. As Jews our advantage in the past, though, was that we were outsiders critically looking in; today Jews sit at the right hand of the goy in the White House advising him whom to bomb next in order to advance the Empire.

To be outsiders in a nation or an empire is not such a terrible thing. Keeping critical and alert has allowed the Jewish people to survive all sorts of imperial disasters over the millennia — the Greeks, the Romans, Islam in Spain (which went from Golden Age to Inquisition in a few centuries), the Crusades, Reformation Europe, the Russian Czars, Nazism. This particular empire is neither the first nor the last to attempt to seduce us to join up. But we'd better not: it's our job to be critical outsiders, both for our own survival and for that of the planet.

As a child I never fell for the seduction of patriotism. It seemed so arbitrary, who's an American and who's not. If my relatives hadn't emigrated, who would I be? Since I was also at core an idealist and a utopian-another Jewish tradition?-I wanted to skip all that obviously stupid and dangerous stuff that gave rise to wars and racism. In 1965 I began to identify myself as a socialist and an internationalist. I still am an internationalist since old religions die hard.

That brings me to the toughest problem of all, Israel. If we look closely and critically at Israel today it's possible to see the downside of nationalism, whether religious or secular. There is a well-documented continuity over the last almost forty years between the Labor Party and Likud in their policies toward the Palestinians and settlement in the Occupied Territories. I am heartbroken over the moral and spiritual costs of the Jewish State to the Jewish People. I challenge anyone who thinks of me as a traitor to my people or a self-hating Jew, both of which I've been called, to visit Palestinians in the West Bank or East Jerusalem for as little as one-half day. Every Jew needs to see the misery 
and humiliation which our Jewish nationalism and racism have wrought. These are not Jewish values, or at least my Jewish values.

Nor does the Jewish state guarantee Jewish safety and survival. My father was a military man and as such was always pessimistic about the long-term survival of Israel. He easily perceived Israel's strategic weaknesses in both geography and demographics. The only way Israel has survived so far has been to ally with the sole remaining imperial power in the world. But all empires fall, as Jewish history so clearly tells us. Maybe they should have allied with China.

This year I visited Israel with my family for the first time. I learned that far from being culturally retro, which is the way I used to think of it — a small, socialist, anti-materialist nation-Israel is really an avatar, way ahead even of California. Israel is America's future: militarized, racist, religio-nationalist, corporate, riven with so many internal splits and hatreds that only the existence of a perpetual enemy keeps the nation from exploding. If we don't organize to stop the current direction in this country, thirty years from now we will be Israel.

"Genug!, enough!," as my father would say if he were here, "You've made your point!"

Ok, Jake, you're probably right. To show what a good Jewish boy I am I'll give Bertha the last word. After all, she started this piece.

In 2003 a documentary called The Weather Underground was released. It was made by two young men, Sam Green and Bill Siegel, both Jewish, and was well received by audiences and reviewers. It was even nominated for an Oscar.

My brother David, who's eight years older than I, had never been comfortable with anything about the Weathermen. At the time I treated him contemptuously because he wasn't "revolutionary," and on top of that he had to live with the misery which my parents endured for the seven years I was a fugitive. Over the years our way of dealing with the issue was to not talk about it. But after he saw the movie, David became so smitten with The Weather Underground that he set up two showings, one in Great Barrington, Massachusetts, where he lives part-time, and the other at a Jewish film festival in suburban Essex County, New Jersey, where our family is from.

About four hundred people attended the showing at the Jewish Community Center in West Orange. The average age of the audience was probably around 65. My mother was sitting in the second row. After the movie I was answering questions from the audience when my mother waved her hand, interrupting. "I have a question! I have a question!" she shouted. "What's your question, Mom?” I asked.

She paused just long enough for the audience to wonder what she was going to say. "I've waited thirty years to ask you: How could you do this to me?"

\section{Endnotes}

1. Talk given at the New Mexico Jewish Historical Society Conference, "Jews in War and Peace," held in Albuquerque, NM, on Nov. 12, 2005. 